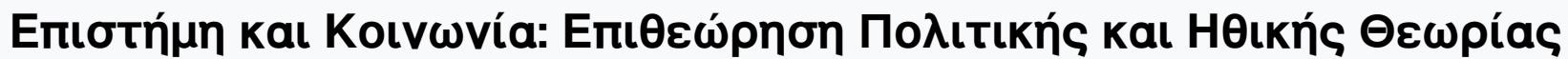

Tóp. 13 (2004)

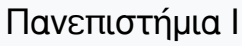

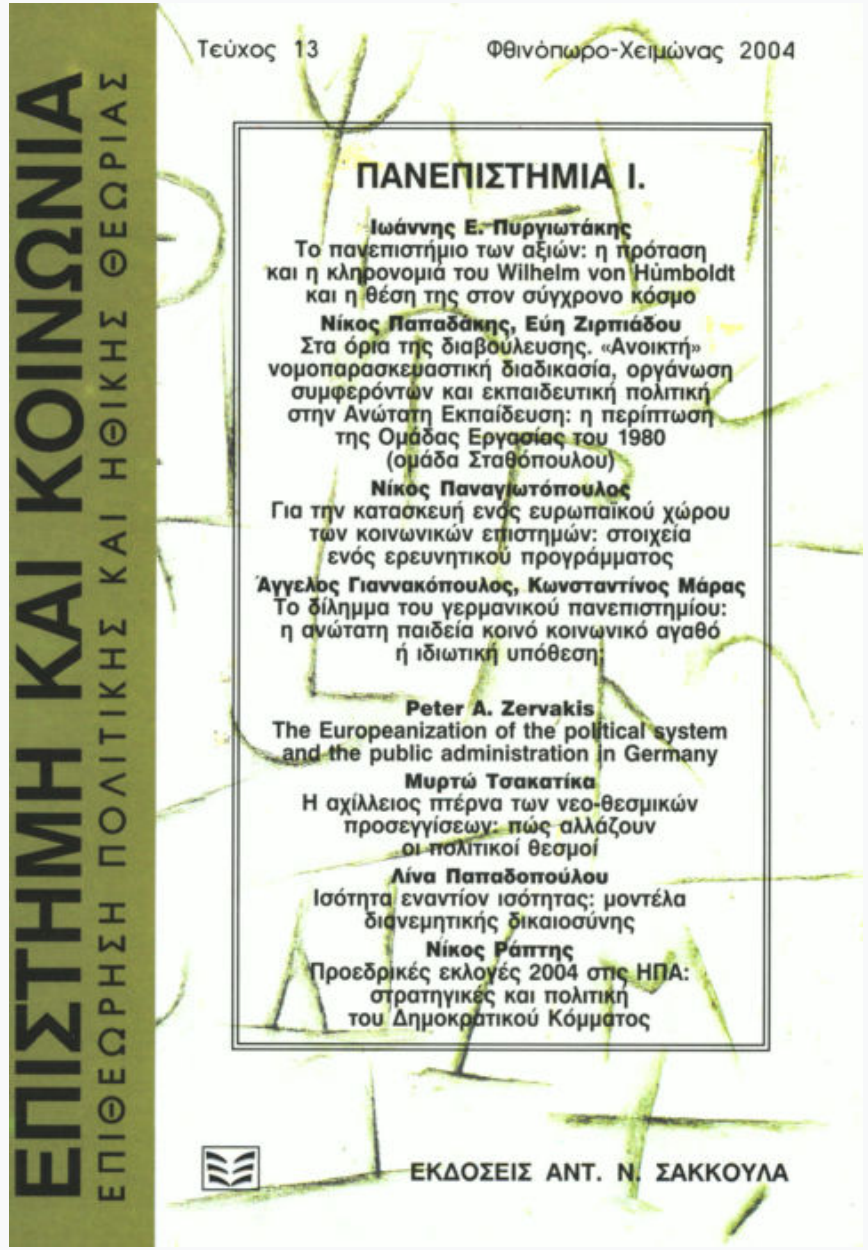

The Europeanization of the political system and the public administration in Germany

Peter A. Zervakis

doi: $10.12681 /$ sas.579

Copyright $\odot 2015$, Peter A. Zervakis

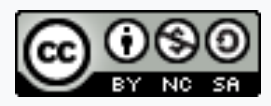

Aঠ¿ıа Xpńбnৎ Creative Commons Attribution-NonCommercial-ShareAlike 4.0.

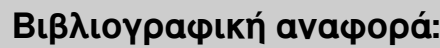

Zervakis, P. A. (2015). The Europeanization of the political system and the public administration in Germany. Eпıбтń $\mu$

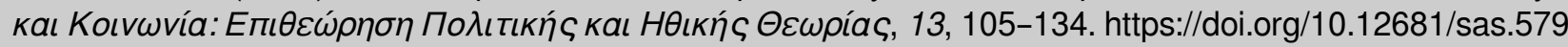




\section{The Europeanization of the political system and the public administration in Germany}

\section{Peter A. Zervakis*}

This article is an analysis of the main patterns of institutional continuity and change that characterize the German federal political system under the influence of 'Europeanization'. It shows the different degrees of Europeanization to which the German political institutions and public policies have already adapted. Introducing some guiding theoretical approaches that have been applied to raise the analytical validity of Europeanization, it attempts to explain the range and the degree to which the German state and its domestic polities, politics and public policies have been integrated into the EU governance system. After analysing the core institutional features of the German federal system which generally resist European integration, it presents some evidence on the adjustments made to the (reunified) German intergovernmental system, designed to further stimulate European integration. Finally, it presents a brief summary of the lessons learnt from 'Europeanizing German federalism', in order to examine whether typical patterns explaining the Europeanization of the EU member states can be identified.

\section{Introduction}

In 1943, from his exile in the US, the renowned German novelist, Thomas Mann, broadcast a warning to the listeners of Radio New York. He claimed

* Ph.D., project coordinator Europe Bertelsmann Stiftung. The ult thor wishes to express his deepest gratitude to Roderick Parkes, M.A., for commenting on the paper. 
that Adolf Hitler wanted the 'Germanization of Europe' (Knodt 2000: 32, 53). Contrary to this dreadful vision, Mann dearly wished one day to see the 'Europeanization of Germany'. Mann's then utopian leitmotiv has become our modern political reality. Germany has been successfully multilaterally tamed (Katzenstein 1997) and has voluntarily integrated its political system into the European Union (EU). Thus, the German case has proved that integration works by institutionalizing co-operation and transforming its member states' particularistic national interests in the long run:

Crucially, the community idea is not meant to eliminate the national state but to create a regime which seeks to tame the national interest with a new discipline. The challenge is to control at societal level the uncontrolled reflexes of national interest in the international sphere (Weiler as cited in Kohler-Koch 1998: 269).

But though 'Europe matters' (Knill \& Lehmkuhl 1999) in German policymaking and, without doubt, the EU has a clear impact on the German political system, especially with regard to the Europeanization of public policies, there is a relatively high resistance to domestic institutional and structural change prompted by top-down legal interventions originating from Brussels. As a consequence, especially in the last decade after unification, Germany appears to its European neighbors as the 'sick man of Europe' (The Economist) because of its proven inability to cope economically and politically with the liberalization and competition challenges of globalization (Hopt, Kantzenbach, Straubhaar (eds) 2003). The frustrated German political class seems internally and externally too weak to assume with some credibility its traditional locomotive function revitalizing European integration (Kühnhardt 2003).

In the following, I want to analyze the main patterns of institutional continuity and change that characterizes the German federal political system under the influence of the somewhat ubiquitous and trendy umbrella term 'Europeanization'. The first section, consequently, tries to conceptualize Europeanization. The second shows the different degrees of Europeanization to which the German political institutions and its public policies have already been adapted. It will introduce some guiding theoretical approaches that have been applied to raise the analytical validity of Europeanization. They may explain to which range and degree the German member state and its domestic polities, politics and public policies have been integrated into the EU governance system. The third section analyses the core institutional features of the 
German federal system, including public administration, which generally resist European integration. Then, in the fourth section, some evidence is presented on the adjustments made to the (reunified) German intergovernmental system, which were designed to further stimulate European integration after the Maastricht and Amsterdam Treaties. Finally, the lessons learnt from 'Europeanizing German federalism' are briefly summarized, to see whether typical patterns explaining the Europeanization of the EU member states can be located.

\section{The ambivalent nature of Europeanization}

There is no general consensus in the scientific community on a valid definition of the catch-all term 'Europeanization', which has gained some popularity in integration studies literature since its introduction in the 1980s (Zervakis 2003: 295, footnote 75). Yet many definitions are actually of too broad a conception for our purposes: for Cowles, Caporaso and Risse (2001: 3) Europeanization means:

... the emergence and development at the European level of distinct structures of governance, that is, of political, legal, and social institutions associated with political problem solving that formalize interactions among the actors, and of policy networks specializing in the creation of authoritative European rules.

Also they refer to the equally open concept of the finalité of the EU's emerging political system (Leslie 2002: 218-220) and emphasize too strictly the formation of political institutions by elite networking at the EU level. Theories, which focus only on an endpoint, risk ignoring the 'sui generis' process of the multi-level European governance (European Commission 2001: 11; Jachtenfuchs \& Kohler-Koch 2003: 18). In this study, 'Europeanization' refers to the 'EU-isation' or 'EU-Europäisierung (Europeanization)' of national institutions (Kohler-Koch 2000: 12, 27) and thus focuses on the problem of the 'central penetration of national systems of governance' (Olsen 2002: 923). In any case, the vast majority of empirical literature seems to deal with the impact of the EU on the member states' national political systems emphasizing policy rather than institutional change (Jachtenfuchs \& KohlerKoch 2003: 36). Therefore, Ladrech's well-established and broadly accepted definition fits better our uses because it rightly points at the adaptive pro- 
cesses of national institutions and their public policies to a changing external environment:

Europeanization is an incremental process re-orienting the direction and shape of politics to the degree that EC political and economic dynamics become part of the organizational logic of national politics and policy-making (Ladrech 1994, 69).

However, Wessels $(1997,36)$ is more precise, when he defines the term 'Europeanization' as an ongoing and time-consuming process, whereby various economic, administrative, social and political actors shift the center of gravity of decision-making from a traditional, strictly national level to a multi-level focus that considers the EU as part of the domestic structure. In this perspective, the EU acts as 'a co-formulator for national political choices' (Zervakis \& Yannis 2001: 153). This concept looks at European policy not as foreign (diplomatic) policy but as an integral part of a new, self-sufficient whole, which has not yet reached its final structure. Not that European integration is a purely supranational procedure: its eminent protagonists are the national governments, and the states remain the 'masters of the Treaties' (Walter Hallstein). However, the Europeanization of domestic political and administrative structures points at a new supranational level, which ideally co-exists among the nation states based on a 'confederal consociation' (Chryssochoou 2001: 2, 26-27; Nettesheim 2003: 31). Thus, the relevant actors in the domestic scene of the member states (politicians and high-level civil servants) need to show a mutual willingness and capability to integrate European interactions into their existing domestic policy-planning and policy-making patterns without necessarily converging with the institutions at EU-level (Bulmer \& Bulmer 2000: 268). Radaelli (2000: 4) expresses this consensus in defining 'EU-Europeanization' rather convincingly:

Processes of (a) construction (b) diffusion and (c) institutionalization of formal and informal rules, procedures, policy paradigms, styles, 'ways of doing things' and shared beliefs and norms which are first defined and consolidated in the making of EU decisions and then incorporated in the logic of domestic discourse, identities, political structures and pubiic policies.

\section{Germany's own way to European Governance}

The evaluation of the impact of European integration on the political and administrative systems of the nationally organized EU member states has 
initiated growing scholarly interest only in recent years (Borkenhagen et al. 1992; Goetz 1995; Wessels and Rometsch 1996; Luthardt 1996; Cowles, Caporaso, and Risse 2001: 3; Sturm and Pehle 2001: 249; Knill 2001). This is mainly due to the fact that, in public opinion, the nation state organized as a parliamentary democracy has for long been identified as the only democratically legitimate form of governance (Zervakis 2003: 283). Meanwhile it belongs to conventional wisdom in integration studies that Europeanization has influenced virtually all sectors of the political system of Germany: from polity (institutions) and politics (formulation of political objectives) to various public policies -but its effects on each of these areas differ in size and scope. Furthermore, a set of theoretical proposals has been developed to explain convincingly the ambivalent effects that the difficult process of Europeanization causes in its confrontation with the different horizontal and vertical layers of the German federal governmental system. In the following, the theories will be applied only generally to the basic institutions and policy sectors of the German political system to give an idea of the varying degree of the broader adaptive process that Germany, as a member state, has experienced through European integration. In this way the explanatory strength of those theories will become clear in a middle range perspective (see Table 1 and Sturm / Pehle 2001: 14-26).

\section{Table 1: The Europeanised German political system}

\begin{tabular}{|c|c|c|c|}
\hline Sectors & Dimension & $\begin{array}{c}\text { Degree of Europeanization } \\
\text { from 1 (state autonomy) } \\
\text { to 10 (European State) }\end{array}$ & $\begin{array}{c}\text { Theories explaining } \\
\text { Europcanization }\end{array}$ \\
\hline Federal Government & polity & 4 & multi-level 'win-set' \\
\hline Bundestag (Parliament) & polity & 3 & multi-level 'win-set' \\
\hline Bundesrat (Federal Council) & polity & 3 & 'joint decision' thesis \\
\hline Länder (States) & polity & 6 & 'joint decision' thesis \\
\hline $\begin{array}{c}\text { Bundesverfassungsgericht } \\
\text { (Federal Constitutional Court) }\end{array}$ & polity & 7 & 'fusion' \\
\hline Interest Groups & politics & 7 & 'political networking' \\
\hline Political Parties & politics & 3 & 'political culture' \\
\hline Monetary Union & policy & 9 & 'institutional \\
isomorphism'
\end{tabular}

Source: Roland Sturm / Heinrich Pehle: Das neue deutsche Regierungssystem, Opladen 2001, 252 (translated by the author). 
The modest Europeanization gains of federal government can best be explained by applying the formally dominant multi-level 'win-set' theory (Bulmer / Bulmer 2000: 280). Is the nation-state revitalized by its symbiosis with the EU, as the inter-governmental approach (Milward 1992; Moravcsik 1999) suggests, or does it, conversely, lose its significance, as the federalists assume? This theory suggests that the federal government has been able to optimize its national resources and copes more or less efficiently at the European level.

The pragmatic 'joint decision' thesis, on the other hand, explains how and why the compatible executive co-operative federal structures in Germany and the EU may lead to a stalemate -a 'joint decision gap' (Scharpf / Reissert / Schnabel 1976; Scharpf 1994)-, if institutional involvement in decision-making by permanent negotiations is too rigidly fixed by 'political interconnectedness' (Politikverflechtung) (Luthardt 1996). Any decision on EU-legislatio:1 demanding a unified German vote is usually undermined by the absence of a powerful German decision center because of the antagonistic relations between Bund and Länder. Länder governments, which dominate the less Europhile Bundesrat, are typical role models for the intensive Europeanization of German executive federalism at the expense of the national (Bundestag) and the sub-national parliaments (Landtage) which lose further legislative competences to Europe and thus transparency and legitimacy. The Länder administrations are forced to collaborate not only with the Bund in Berlin but also directly with the core EU-institutions in Brussels to secure their economic and political survival. But the predicted 'joint decision trap' has not worked out when the German government, with its prime objective of safeguarding the introduction of the Euro (and EMU), actively supported further sacrifices of national sovereignty in the negotiations leading to the Maastricht (but less so in the Amsterdam and Nice) Treaties (Beuter 2002: 93).

The dynamic 'fusion' thesis (Wolfgang Wessels), on the other hand, explains the high degree of Europeanization within the German Federal Constifutional Court: the growing significance of EU legislation in the national German legal arena necessitates a closer institutional cooperation with, and to the advantage of, the European Court of Justice in Luxembourg. Meanwhile, the symbiosis between German and EU agricultural policies is casily explained by the fact that in this policy field the EU and the member states share and manage powers, funds and regulatory instruments (package deals are the norm).

The 'political culture' approach highlights the traditional 'beliefs systems' 
of the national political parties and clearly demonstrates the inherent limits of the German (and of the other member states) political parties to Europeanize at all because of the inexistence of an informed European demos. In spite of the introduction of direct elections to the European Parliament for several decades, a European space for political party competition has not yet been evolved (Johansson \& Zervakis 2002: 13; Mair 2000; Jachtenfuchs \& KohlerKoch 2003: 19, 39-40).

The best example for 'institutional isomorphism' is the Euro-Union, whereas environmental policy is a good example of how policy sectors become Europeanized by the creation of transnational 'regulatory regimes'. Regional policies and interest groups follow best the 'political networking' assumption because they are non-hierarchically organized, as regards competences shared between the EU, the nation-states and the regions.

Justice and home affairs policies are, finally, good examples of how 'policy learning' has led to legal Europeanization even outside the EU legislative area (see the Schengen Accords). Member states learn through 'best practice' and role models how to accommodate each other or to converge.

Today's hard empirical evidence shows that the core democratic institutions in Germany (including the directly or indirectly elected federal government, parliament and Federal Council, as well as the strong political parties acting as institutionalized intermediaries between the polity and the politics dimensions which compete for political power gained by national elections) have successfully resisted Europeanization, as far as their convergence to a European state model is concerned (see Table 1 and Jachtenfuchs / KohlerKoch 2003: 37). Though their policy decisions are not any longer shaped independently from Europe (degree 1), they are a long way from a fused system of European Governance (at the average degree only 3-4 in a scale up to 10 ). Conversely, the more economically oriented public policies have been Europeanized more eagerly and easily (at the average degree 9-7): agriculture (degree 9), currency union (degree 9), environment (degree 8), regional policies (degree 8), justice and home affairs (degree 7), and the majority of societal interest groups like farmers, professional, business and employers associations, trade unions etc. (degree 7). These policy-areas and actors are all more closely related to the above mentioned Europeanized political fields, in which hard decisions are made today mainly at the European level. These institutional actors from the member states' civil society increasingly focus their individual demands at the EU-level by establishing representative fede- 
ral networking structures in Brussels (like COPA-COGECA). Hence, their influence is gradually reinforced, while they organize their transnational presence in rather loose federal structures in part to become influential and most 'gaining receptors of the European negotiation process' (Zervakis / Yannis 2001: 154).

In Germany, there is a sharp contrast between the reality of an ever growing number of Europeanized public policy sectors (with high degrees of Europeanization), which are regulated by comprehensive 'package deals' (Maastricht, Amsterdam and Nice) and binding decisions in Brussels, and resistant German political institutions (with relatively low degrees in Europeanization (Wessels / Rometsch 1996: 77). This leads to a long-term misperception of the real strength of the EU by national elites. 'The European decision-center is located in Brussels', as Siedentopf enthusiastically concludes. But he may be overstating developments in assuming: 'In the meantime nearly all activities of the national administrations (of the member states) are mainly determined by legal regulations derived from supranationality' (Siedentopf 1999: 84-85). Politicians, the media and parts of the academic community have been largely unaware of the full impact of the slow but constant changes that occurred in most of Germany's public policies between 1950 and 2000 (see Table 2; Schmidt 1999: 11-12). It is evident that degrees of Europeanization in all policy fields and within specific policies vary in time and scope depending on whether political decisions are still taken solely by national processes (1) or already by a joint Community process (5). On average, decision-making in all of Germany's national public policies is carried out by processes which do not conform to, what might be termed, a Community decision process (they were rated 2.4 in 2000) but they certainly show a growing tendency towards further Europeanization (in the sense of 'Communitarisation'). Thus a discrepancy can be diagnosed between perceived and actual sovereignty transfers to Brussels. Evidently, public opinion moulders show little interest in differentiation, and perhaps even less, in the technocratic, relatively opaque and output-criented nature of the incremental Europeanization process. For instance, the verdicts of the European Court of Justice in Luxembourg have successfully transformed national judiciary but only as concerns the workings of the German Federal Constitutional Court (7, see Table 1) and the general access to the EC/EU-Judiciary (4 in 1992/2000, see Table 2). However, the overall German legal system is merely on the verge of becoming integrated (1.8 in 2000, see Table 2 and Hess 2003). 
Table 2:

The Europeanization of public policies in Germany, 1950-2000

\begin{tabular}{|l|c|c|c|c|c|}
\hline Policies (in selection) & 1950 & 1956 & 1968 & 1992 & 2000 \\
\hline Foreign Policies (average degree) & $1^{*}$ & $1^{*}$ & $2^{*}$ & $2,5^{*}$ & $2,5^{*}$ \\
a) Military / Diplomacy & 1 & 1 & $1 / 2$ & 2 & 2 \\
b) Foreign Trade & 1 & 1 & 3 & 4 & 4 \\
\hline Institutional / Constitutional Policies & 1 & 1 & 1 & 2,3 & 2,7 \\
a) Direct election of the EP & 1 & 1 & 1 & 4 & 4 \\
b) EC/EU Citizenship & 1 & 1 & 1 & 2 & 3 \\
c) Direct election of EU executive & 1 & 1 & 1 & 1 & 1 \\
\hline Justice and Home Affairs Policies & 1 & 1,2 & 1,4 & 1,6 & 1,8 \\
a) Public security, law and order & 1 & 1 & 1 & 1 & 2 \\
b) Access to the EC/EU-Judiciary & 1 & 2 & 3 & 4 & 4 \\
c) Civil Code & 1 & 1 & 1 & 1 & 1 \\
\hline Social Policies & 1 & 1,2 & 1,3 & 1,6 & 1,9 \\
a) Unemployment Security & 1 & 1 & 1 & 1 & 1 \\
b) Public Health Security / Services & 1 & 1 & $1 / 2$ & $1 / 2$ & 2 \\
c) Equality & 1 & 2 & 2 & 3 & 3 \\
d) Labor Migrants & 1 & 2 & 2 & 4 & 4 \\
\hline Education and Science & 1 & 1 & 1,4 & 1,8 & 1,8 \\
a) School System & 1 & 1 & 1 & 1 & 1 \\
b) Universities / Vocational training & 1 & 1 & 1 & 2 & 2 \\
c) Research & 1 & 1 & 3 & 3 & 3 \\
d) Culture & 1 & 1 & 1 & 1 & 1 \\
\hline Economy and Labor Market & 1 & 1,2 & 1,8 & 2,5 & 3,2 \\
a) Agriculture & 1 & 1 & 4 & 4 & 4 \\
b) Communication & 1 & 1 & 1 & 2 & 2 \\
c) Monetary/Currency & 1 & 1 & 1 & 1 & 5 \\
\hline Environment and Energy & 1 & 2 & 2 & 2,5 & 2,5 \\
a) Energy & 1 & 2 & 2 & 2 & 2 \\
b) Environmental Protection & 1 & 1,2 & 1,5 & 2 & 2,4 \\
\hline Average for all public policies in Germany & & & & & \\
\hline
\end{tabular}

Source: M. G. Schmidt: Die Europäisierung der öffentlichen Aufgaben, Bremen 1999, pp. 11-12 (translated and abbreviated by the author).

* The figures symbolise:

$1=$ 'all policy decisions by national process'

2 = 'only the beginning of Community decision process'

$3=$ 'policy decisions in both but national activity predominates'

$4=$ 'policy decisions in both but Community activity predominates'

$5=$ 'all pelicy decisions by joint Community process'

One may lament that the functional approach to integration that emphasizes solely efficiency, lacks transparency and parliamentary democracy, i.e. broader popular enthusiasm (electoral support of European Parliament's 
participation in the EU legislative process) and mutual trust of the citizens (legitimacy). One can hardly be surprised by the fact that in the last 50 years or so the German governmental system has begun to converge with the EU and has lost its traditional nation-state autonomy to a considerable degree (Kohler-Koch 1998: 263-264, Kohler-Koch 2000: 13). On the other hand, this does not mean that European governance has simply replaced the national political system. If this were so, we could end our reflections on institutional continuity and change within the German political system in view of European membership right here, and turn to Hix's bold suggestion 'The Political System of the European Union' (Hix 1999). However, not just since European integration accelerated in the direction of political union in the late $1980 \mathrm{~s} / 90 \mathrm{~s}$, has Germany been fully transformed into a 'penetrated political system' (Rosenau 1969; Sturm / Pehle 2001: 13). Direct European legal and political 'interference' has been permitted by the openly-Europhile German Basic Law/Constitution (Preamble, articles 23 and 24, no.1) since the application of the Rome Treaties. Indeed, from its constitutional beginnings in 1948/49 and, especially in its adaptation to the Maastricht Treaties, the German government has welcomed and legally enabled the broad transfer of sovereignty rights to international organizations, including the EU, and has thus voluntarily integrated Germany's future in Europe and the West (Bulmer / Burch 2000: 277; Goetz 1995: 93). It was only formally limited by the German Federal Constitutional Court's Maastricht decision (Zervakis 2003: 310; Steffani 1997: 162-167). Thus, the post-war Federal Republic's 'Drang nach Westen' has further been legitimated by its integration 'in the process of creating an ever closer union among the peoples of Europe...' (Article A, Treaty on the European Union).

Furthermore, in analyzing the Europeanization of national political systems, intergovernmental relations are of special significance, particularly in strongly decentralized or federalized polities. Not only do they comprise all political, institutional, procedural and organizational facets of possible and traceable changes in the federal administration, but the relations between local, regional ('sub-central' or Länder) and federal governments are also highly political and their interrelations a good indicator for testing the influence of Europeanization. Because the federal structure of the German polity is historically and constitutionally safeguarded, the close relations between the Bund (federal government and the European Union), the Länder (states) and inter-Länder relations as well as the local level (Städte and 
Kommunen) are crucial to the functioning of the German cr-operative federalism (Verbunds-, or Verflechtungsföderalismus). They influence nearly all dimensions in German political life (Sturm 2003: 117). European integration is thereby a potentially powerful co-factor of domestic change and has some impact on those relations. The Länder's executives, on the other hand, are in a relatively strong position mainly in the German domestic federal arena. They are political, governmental and administrative actors with their own constitutional rights to co-decide in federal legislation. This renders German co-operative federalism, with its decision-making processes in the Bundesrat, unique, not only in the EU, but also amongst other federal systems (Steffani 1997: 64; Sturm 2003: 127). The Länder governments and, especially, their indirectly elected presidents (Ministerpräsidenten) have good reason to fear all sorts of power-erosion at the European level of governance, a development which would be to the advantage of the Bund. Therefore, they use their federal representation in the German Federal Council to shape not only key aspects of federal policy but also to ensure that their interests, assets and relative institutional strengths are not changed decisively by the effects of the integration process (Leonardy 2002b: 27).

However, the key question in this respect is to what extent national politics, governmental-administrative structures, policy-making procedures and the substance of public policies have really been changed in reaction to growing political and economic interventions from Brussels (top-down approach) as a result of dynamic German EU membership. Here the general assumption is that European integration has triggered a more informal adaptation process amongst the Länder, as far as their direct interest representation in Brussels is concerned. But the 'dramatic increase in Community and EU affairs' has not seriously challenged the basic institutions of decisionmaking in the German federal system between Bundesregierung and Bundesrat (Goetz 1995: 91; Wessels / Rometsch 1996: 99). On the contrary, Europeanization has supported and, in some cases, even reinforced the core features of the intergovernmental German system.

\section{The German federal system's persistence to the EU's integrative pressures}

If we assume that soft domestic factors (like constitutional history and specific traditional elements in political culture), rather than dynamic Euro- 
pean integration, have shaped German intergovernmental institutions and federal arrangements in the last half a century (Jachtenfuchs / Kohler-Koch 2003: 36), then we can find at least seven features inherent to the system. They have decisively shaped the persistence of German intergovernmental relations, which are practically immune to political change from above:

1. German federalism has favored the vertical and horizontal sharing of powers, responsibilities and resources (Verbundsystem) rather than their separation and delineation into different layers of government like in the USA. Thus, the Länder's executives extended their institutional influence on key federal legislation by extensively using the Bundesrat's power of veto and supported by Federal Constitutional Court's verdicts (Rechtsstaatsprinzip). In the meantime, more than $60 \%$ of all federal laws, and by far the most important ones, require Bundesrat's approval (zustimmungsbedürftige Gesetze) (Hesse / Ellwein 1992: 286).

2. Because the majority of national legislation requires the Bundesrat's participation and approval, close collaboration, co-operation and co-ordination are essential between Bund and Länder and between the Länder in all stages of policy-making for joint policy- and decision-making in Germany's stable co-operative federalism. This favors bargaining solutions at every level (Knill 2001: 91-92). For this purpose, strong multi-level inter-linkages of policy-making can be identified between the federal center (Bund) and subcentral (Länder) levels of Germany government. Decision-making mechanisms need a broad consensus mediated by strong parliamentary political parties (structured in federal, regional and local levels) to avoid stalemate, whenever the opposition parties hold a majority in the Federal Council (Steffani 1997: 145). No side can impose political solutions on the other and unanimity is often the rule in joint- decision-taking. If this is not the case, the 'joint-decision-trap' can be triggered (Scharpf et al. 1976). Since the federal government, generally speaking, has no hierarchical administrative authority over the Länder's executives, intergovernmental co-ordination has to be obtained by complicated negotiations between autonomous administrative units. In these relations, the leading role of the Bund is counterbalanced by the Länder's experience in administration and implementation. Such a structurally and procedurally interlocked system of federal and regional executives, with no clear majority in the Federal Council for the governmental coalition, explains why only incremental changes to the balance of power occurred in 
Germany between the 1970s and 1982 and again, between the 90 s and today (Jeffery 1999: 50-51; Sturm 2003: 128-129).

3. The continuous extension of federal legislative powers (exclusive, concurrent and framework legislation) into the Länder's core competences (education, research, culture, internal affairs) and the determination of the Bund to use its powers fully, resulted in a high degree of Germany-wide legal, economic and social standardization at the expense of the Länder parliaments' legislative powers (see, for instance, the Bologna Process in higher university education in Zervakis 2004). Therefore, the increased Länder participation in federal legislation can be regarded as a partial compensation for the loss of the legislative capacities in the states' parliaments. This high degree of standardization can be seen as a direct consequence of the stipulations in the Basic Law, in combination with the Federal Constitutional Court's verdicts emphasizing categorically 'the uniformity of living conditions' throughout the territory of the Federal Republic. This has proved to be counterproductive to the protection or promotion of diversity. However, contrary to common belief, German federalism is neither designed to protect the rights of ethnic, national and/or religious minorities nor to preserve particular regional identities or promote cultural, economic or social diversity (Goetz 1995: 95).

4. On the other hand, administrative competence for the execution of most federal and Länder legislation lies with the Länder. Although the German Constitution foresees certain exceptions (i.e. in foreign service, federal tax administration, army, border guards, railways, post office, audit etc.) where the Bund is empowered to create federal administrative authorities with their own regional substructures, the administrative capacities of the Länder are far superior to those of the federal institutions. For instance, in 1992, about 6.3 million people were employed in the German public sector, although this figure decreased dramatically (in 2003: 4.76) within a decade of reunification (Goetz 1995: 95, footnote 3; Statistisches Bundesamt 2004: 1). Direct federal employment accounted in 1992 for only about 625,000 (in 2003: 491,000) people (including soldiers), whereas 642,000 civil servants (in 1992) were separately employed exclusively by the then Federal Post Office (in 2002: 542,000 ), and 434,000 worked only for the public railways (in 2002: 249,912) and, therefore, were statistically counted only as indirect federal employment. In the meantime, post office and railways have been transformed into public listed companies under private law, thus lowering the size of federal emp'oy- 
ment decisively because private employment law is increasingly applied to the employees there. But law implementation by the Länder is also under intergovernmental co-ordination, since there is an extensive institutional network for harmonizing implementation practice among the German states, and vertical links between federal and the Länder's technical departments are the rule.

5. Also there is clear leadership by the executives in the intergovernmental process, marginalizing the parliaments of the Länder (Landtage) and the Bundestag that are largely excluded from the highly fragmented and decentralized intergovernmental decision-making process, including the European level. At the top of the joint policy-making system there are regular meetings among the Länder's Presidents who then meet together with the Chancellor. In departmental terms, state ministers confer regularly with Federal ministers, who are all relatively free from political intervent by their heads of government (Ressortprinzip in article 65 Basic Law; Ismayr 2003: 459). Beneath the top political level, an uncounted network of administrative committees of different status, and ad-hoc meetings has been established. These are constituted by higher and medium career public servants. This well-functioning bureaucratic co-ordination machinery in the tradition of executive or administrative federalism or Verwaltungsföderalismus (Hesse / Ellwein 1992: 88) prepares not only top-level political decisions but harmonizes and synchronizes the smooth implementation of public policy. Landtage and Bundestag have a hard time influencing and scrutinizing this intergovernmental policy-making and implementation (Wessels / Rometsch 1996: 90-92; Sturm / Puhle 2001: 57-58). The fragmented but institutionally stable German administrative federalism is resistant to any radical political change by party democracy and leaves virtually no space for political leadership because there are only limited chances for federal government to guide and control the administration of federal programs at the Länder level. As a consequence, reforms are somewhat evolutionary, incorporated in endless negotiations into package deals between the different levels of the German governmental system than introduced top-down (Knill 2001: 92).

6. To complete the picture of the complex nature of a stable German federal system, albeit one which has not responded well to external pressures, it is necessary to reflect on the strong political influence of the highly autonomous German public administration. Though constitutionally-speaking it is purcly instrumental to politics (article 20 of the German Basic Law foresees a clear division of power between policy formulation and implementation, and 
binds the administrators to the law), German bureaucracy has long legalist traditions, which preceded democracy (Rechtsstaat). The administration effectively influences the often open-ended and incomplete legislation during the implementation stage. Political and administrative arenas are partly overlapping because of urgently needed bureaucratic expertise (university and privately organized think tanks are of minor significance; see Thunert 2003: $33,35)$ that decisively shapes policy-making, and has seen the successive politicization of the top ranks of the civil service (politischer Beamter) by common party affiliation with the deputies, and the consequent professionalization of politicians (many of whom are lawyers and higher civil servants). Thus, in contrast to the UK where politicians set the administrative agenda, in Germany there is a characteristic strong and continuous 'interlinkage of politicians and bureaucrats' (Knill 2001: 93) during policy formulation, decentralized implementation and enforcement in the fragmented German federal system giving civil servants a rather autonomous, political influential and powerful position within the fragmented German political system. Thus the reform ability of the flexible German bureaucracy is less politically inspired but follows the given pattern of incremental self-adaptation with respect to existing tracitions and principles.

7. German federalism is characterized by a virtual absence of regionalist or ethnic political cleavages. European integration has done little to upset regionalist sensibilities, and thus incite opposition to its progress. Criticism of Germany's European policy from the Bavarian government (one of the few Länder and city-states like Hamburg with a strong historical identity and legitimacy dating back to the times of Napoleon) remains the exception rather than the rule. Although politicians and administrators in the German states have been worried about the impact of Europe on their Länder's position, it has less to do with regionalist traditions than with their goal of gaining and maintaining powers, financial resources and influence as well as a distinct policy profile in the multilayered Europeanized policy-making system (Sturm 2003: 119-123).

However, intensifying European integration has proved systemically compatible with the German mode of governance: multiethnic confederal European governance resembles in many ways the relatively ethnically homogeneous federal German 'consensus model' which, at the same time, has shown a remarkable openness to Europe since its beginnings (Bulmer / Bruch 2000: 287; Lijphart 1999: 33-34, 42- 47; Nettesheim 2003). Both concentrate on close multi-level administrative 'ex- post co-ordination' (Derlien 2000: 56) 
and autonomous bureaucratic participation in the highly fragmented political decision-making process (Beteiligungsföderalismus in Sturm / Pehle 2001: 250), clearly lacking efficiency, democratic transparency and parliamentary scrutiny (Hölscheidt 2001: 118). But the intransparent 'comitology' system in the EU (Bünder / Friedrich 2004: 19), on the other hand, is staffed with all sorts of experts from all the member states' civil services and permits international co-operation in a 'multi-level' institutionalized bureaucracy 'towards a new system of shared government' (Wessels 1996: 80). The multiple institutionalized interactions between the national and the European levels are highly rewarding with regard to multi-issue bargaining and informal reciprocity between the EU and the member states (see figure 1).

\section{Figure 1: Institutional and administrative interaction in Germany over EU position}

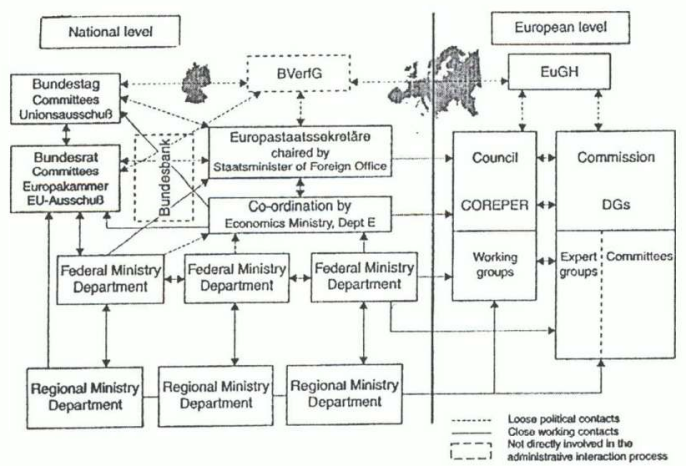

Source: Wessels, W. \& Rometsch, D. 1996: 'German Administrative Interaction and European Union. The Fusion of Public Policies', in: Mény, Y., Muller, P., Quermonne, J.-L. (eds), Adjusting to Europe. The Impact of the European Union on National Institutions and Policies, London: Routledge, 73-109.

Growing Europeanization pressures and interventions from Brussels have supported and sometimes reinforced in several characteristic ways the basic features of German administrative federalism. Administrative federalism al- 
lows only evolutionary self-adaptation within the strict limits of existing intergovernmental relations and administrative traditions without necessarily leading to an institutional convergence (Bulmer /Burch 2000: 268):

1. Since Maastricht, German intergovernmental relations have become increasingly Europeanized in substantive, structural and procedural terms. This has resulted in a steady transfer of competences from the national to the supranational level, thus, widening the range of public policy sectors ruled directly by the EU multi-level governance. Brussels established direct economic and political links with sub-national German governments, just as Länder executives struggled to gain improved access to EU-level decision-making process in order to secure own funds. However, in order to smoothly accommodate the EU as a new domestic co-player, the sharing of powers within German administrative federalism had to be readjusted, rather than dramatically changed (Wessels / Rometsch 1996: 99). Therefore, national intergovernmental relations remained the key element in the distribution of powers, responsibilities and resources in Germany.

2. Nor did the German style of intergovernmental decision-making have to be changed to follow Europeanization pressures because decentralized and fragmented joint-decision-making with unanimity, supported by institutionalized veto powers, also characterize the EU decision-making system. Therefore, political and policy effects seem to be similar in both cases. Despite the resistant German Länder's demands for more subsidiarity (Leonardy 2002b: 28 ), there is no clear evidence for a decline in national joint decision-making as a consequence of increased supranational joint decision-making (Goetz 1995: 98; Sturm / Pehle 2001: 28).

3. But legal uniformity in Germany has been further stimulated and widened by the EU's increased legislative output that has completed parallel efforts by the Bund. The rise in EU legislation has also increased further legal standardization efforts by intervening in exclusive Länder competences (regional development, public services, higher education) with growing practical significance (Zervakis 2003: 300-303).

4. Integration could not change national policy implementation either, because the equally fragmented Commission has no resources to impose its views as a 'superbureaucracy' on the national administrations (Derlien 2000: 67). The EU, in general, has no developed administrative substructures on its own and depends more or less completely on the member states' bureaucracies for the implementation of its own legislation and most of its promotional 
policies. It is up to the individual member state to establish the administrative structures and procedures to be used for this purpose. In federal Germany, existing national administrative competences between Bund and Länder have been used to apply to EU matters. Thereby, the predominance of the Länder in the implementation of EU legislation has been successfully secured. On the contrary, the tendency of European, federal and regional executives towards interlocking could explain to a certain degree the suggested 'double joint-decision-trap' (Hrbek 1986) where only evolutionary self-adaptation occurs.

5. The EU has confirmed and even increased the traditional role of political and administrative executives in the policy-making process. On the other side, the Bundestag's direct influence and scrutiny on the federal government's position in Community-related matters has remained rather limited (Sturm / Pehle 2001: 72-73). And even the 'Law on the co-operation between the federal government and the German Bundestag on matters relating to the European Union' from 1993 could not decisively change the predominant position of the German governments in the Union. The Länder legislatures have historically been even in a weaker position to influence European integration. This is mainly due to the fact that the German states, in their attempt to strengthen their roles vis-a-vis Brussels and Berlin, have overemphasized their state executives' legislative functions in the Bundesrat. Consequently, their legislative participation in the Bundesrat on EU affairs was considerably strengthened domestically. With the Amsterdam negotiations it became apparent that the Länder have evolved into 'a force to be reckoned with' (Beuter 2002: 118).

Finally, though the dynamics of European integration have been fully accommodated within the existing fundamental organizational framework of the federal intergovernmental system in Germany, it led to some important functional re-adaptations and formal adjustments in the aftermath of Maastricht.

\section{Adaptation and adjustments of the German intergovernmental system after Maastricht}

Dynamic developments at the European level after the Treaty of Maastricht have lead to some significant political adaptations and formal legal adjustments in German intergovernmental relations, mostly through the in- 
corporation of EU matters into the existing institutional framework of national government (Bulmer / Burch 2000: 287). But in the emerging multi-level European polity, the Länder in particular developed a three-stage more or less defensive strategy to protect their institutional self-interests in Germany and the EU (Goetz 1995: 101; Hüttmann / Knodt 2000: 32). With mixed blessings, they concentrated on demanding

a) an effective subsidiarity as a preventive protection strategy against perceived further excessive EU interventions in certain domestic policy fields falling under their own competence,

b) a better representation and a direct access to the decision-making centers in Brussels, and

c) an increase of their legal participation and political significance in influencing the Federal Republic's integration policy.

Pragmatically seen, only the last objective promised satisfactory results for the Länder because agreement on the other demands depended on the difficult consensus-building mechanism between all EU member states. Meanwhile, because the German government urgently needed the Bundesrat's approval to ratify the Maastricht and Amsterdam Treaties for domestic reasons, the Länder had, in this point alone, a valuable bargaining chip (Hüttmann / Knodt 2000: 33-36; Beuter 2002: 101-104; Goetz 2000: 101-108):

\section{a) Demand for Subsidiarity}

The precise formulation and recognition of subsidiarity as a key constitutional and legal principle of the EU, comprising a clear division of powers between the EU, the member states and the regions with a listing of exclusive EU competences has been a central demand of the German Länder ever since the ratification of the Single European Act and, more intensively, during the negotiations leading to the Maastricht Treaties (Beuter 2002: 102-103; Goetz 1995: 102; Leonardy 2002a). But though the Länder regularly try to restrict Union involvement in regulatory policies, they do not resist additional EU funding for the promotion of regional economic development. At the same time, they criticize somewhat hypocritically the Commission's stronger influence in defining, selecting and controlling the EU funded regional projects and lament the increased 'bureaucratic burden'. The Länder's ambivalence with regard to finances is similar to their position on the Bund's involvement in exclusive Länder policy competences. While the German states stress the need for maintaining their policy autonomy, they take additional subsidies 
and special incentives from the Bund (in co-funding programs and in federal initiatives like the current one by the federal Ministry of Education establishing all-day schooling) leading to the erosion of sub-central policy-making. On the other hand, attempts by the Länder to 'keep the Union out' cannot be realized in the long run because the Länder simply have not the means to counterbalance the expansion of EU promotional and regulatory activities in their regions (Bielzer 2003; Böttcher / Krawczynski 2002).

\section{b) Representing the Länder in Brussels}

Prior to Maastricht the German Länder had already gained some institutional standing at the EU level to somewhat counterbalance their information deficits as regards the federal government. Since the late 1950s, and until the end of the 80s, a 'Länder Observer with the European Communities', which could act only unofficially, was installed in the Bundesrat with offices in Bonn and Brussels. As a kind of passive member of the German delegation to the Council of Ministers, he was to participate at negotiations, but merely to improve the Bundesrat's access to information on Community developments. Though, in 1979, the Länder started to nominate their own representatives in the German delegation to the Council, the information on EU decisions provided by the Observer's office was not regarded any longer as specific enough to satisfy individual Länder interests. Because his function as a direct source of information is limited to the traditional domestic Länder participation in federal legislation, the Observer's office is not meant to be engaged in individual lobbying activities of the Länder influencing EU legislation (Goetz 1995: 103-104; Hüttmann / Knodt 2000: 36-37).

As a reaction, by 1988, all individual (West German) Länder had founded their own liaison and information offices (Länder-, Verbindungs-, or Informationsbüros) in Brussels and the East German Länder soon followed the example. Though the new Länder representations vary significantly in size, personal and financial resources and their effectiveness in influencing EU decisions is debatable, they are seen as essential to the direct personal representation and lobbying of each German state at the Commission. In this sense they are engaged in close political and administrative collaboration on EU matters with the Länder's Permanent Representations for federal matters in the Bund in Berlin (Pahl 2003: 1).

With the strategy of continuous direct representation in Brussels, the Länder executives mastered the intelligence problems of obtaining relevant 
information from the EU institutions and passing them on in time to their relevant administrative units in Berlin and Länder capitals. With the Treaty of Maastricht, effective Länder influence in Brussels was further channeled by the creation of the Committee of the Regions (Art. 198). Though the German states could not prevent the federal government from restricting the Committee's function to advising the EU on regional policy, the Länder acted as a 'prime catalyst' and political agenda-setter for the enthusiastically received 'Europe of the Regions' (Borkenhagen 1992). Through intensive networking with other sub-central regional governments (like the Spanish Autonomous Communities) the German Länder played a key role in creating and strengthening institutions and mechanisms for institutionalized interregional and transnational co-operation in the Union (Conrad 2003). But, in the meantime, the German states have had to painfully learn that their influence in the Committee is rather limited because of seemingly insurmountable policy and constitutional differences between the relatively powerful German delegation ( 24 seats with only 3 seats for elected local government delegates) and the majority of the weaker and heterogeneously structured regional delegates from all the other - mainly centrally governed - member states (Goetz 1995: 104-105).

It is problematic to assess whether the Länder's growing access to decision-making in Brussels is equal to their growing influence at the EU-level. But the increase in institutionalized influence of the Länder led to some decisive changes in national power-sharing with the Bund in EU matters.

\section{c) Adaptation in power-sharing arrangements at the national level}

The Länder have been most successful in realizing their third objective within the domestic context because the necessity of the Bundesrat to agree on the Maastricht Treaty provided them with direct and powerful pressure vis-a-vis the Bund. As a consequence, the power sharing relations between Bund and Länder in EU-related policy-making, which until the 70s had been completely under the dominance of federal government, changed more to the advantage of the German states. At the same time, however, inter-Länder co-ordination, co-operation and joint decision-making concerning EU-related matters in the Bundesrat had to be intensified and were further institutionalized. In order to achieve a consensual Länder position, effective horizontal co-ordination proved to be a precondition for successful vertical co-operation. Besides the factually non-working European Chamber (founded in 1988 and 
rarely in session) and the Co-operation law (in 1993), the Conference of Ministers of European Affairs of the Länder (since 1992) has brought interdepartmental coordination on EU-matters into line with standard federal practice and further domesticated European policy. And the Länder through their European Commission (Europakommission) co-operated extremely closely in developing a common position, especially in the Maastricht negotiations. But this common bargaining eroded afterwards due to political differences between the parties. These adaptive reactions to the progress in $\mathrm{Eu}-$ ropean integration have not been able to really push any of the established features of German Bund-Länder federalism in the direction of a closer institutional convergence with European governance (Bulmer / Burch 2000: 287).

In relation to the ratification of the Maastricht Treaty, the German Basic Law had to be amended in two places to comply with the Treaty's provisions:

- Amendment to article 28 grants Union citizens the right to stand and vote in local government elections.

- Amendment of article 88 transfers powers of the Bundesbank to the European Central Bank.

As a kind of compensation for the Länder's consent to revise the German constitution, the domestically regulated Bund-Länder relations were integrated into the framework of European integration. The constitutional changes, adopted in 1992, include:

- The amendment to article 50 Basic German Law. The Länder received additional participation rights in all 'matters concerning the European Union' through the Bundesrat.

- An addition to article 52 (3) Basic German Law. It provides for the Bundesrat to form a separate European Chamber (Europakammer) to take all decisions concerning EU matters.

- The insertion of a new article 23 Basic German Law on European Union. It upgrades Bund-Länder co-operation on EU matters.

- The revision of article 146 (1) EEC Treaty together with article 23 (6) Basic German Law that already confirms basically established practice. In case of matters in the interest of the Länder the Bund may include Länder representatives in the German delegation but will continue to lead the negotiations. 'Where essentially the exclusive legislative jurisdiction of the Länder is affected' a representative of the Länder executives nominated by the Bundesrat may exercise the rights of the German federation and 
EU Member State as an exception to the rule and only 'with the participation of and in agreement with the Federal government' keeping full responsibility for the federation (article 23,6 ).

For the first time and after hard domestic lobbying from the side of the Länder, the revised German constitution accepts in principle and in complicated language the right of the Länder executives in the Bundesrat to co-participate with the federal government in legislation and administration concerning all EU matters. That the Länder governments are now able through the Bundesrat to impose, under certain circumstances, their co-ordinated EU-related views on the federal government in important policy sectors marks a major change in the Bund-Länder balance of power. Whereas at its inception, European integration was treated as foreign policy and thus the Bund (the German foreign ministry) had sole competence, since Maastricht European policy has been fully integrated into German domestic policy. This means that not only are the exclusive competences of the foreign ministry more and more contested by the other federal ministries (i.e. economic and finance) but the Länder governments via the Bundesrat are now equal actors in those areas in which European integration affects Germany, and have redressed the balance of power with the Bund. However, the possible representation of the Bund in the EU Council of Ministers by a member of a German state government is mainly of 'symbolic significance' (Goetz 2000: 106). As a consequence, EUrelated decision-making has finally been legally integrated into the predominantly German federal principle of sharing powers and responsibilities between the Bund and the Länder governments. Additionally, Article 23 constitutionalizes, specifies and extends only marginally the Länder's participatory rights, and only in exceptional cases (Leonardy 2002b: 31). Together with the Bund-Länder Co-operation Law (in 1993), it provides for increasing co-operation procedures in EU-related matters: Where Länder interests are concerned in exclusive federal EU legislation, the Bund is not bound by the Bundesrat's majority view but just has 'to take into account the opinion of the Bundesrat' in its negotiations (article 23, 5). But when the Länder's legislative powers, their authorities or their administrative procedures are directly affected by the EU, the Bundesrat's opinion needs to be given 'due consideration' in the decision-making of the Bund. If no agreement can be reached between federal and sub-central institutions, then a decision taken by the Bundesrat with a two-thirds majority is binding on the federal government. However, 
the federal government's approval is still required in matters with budgetary implications for the Bund (Goetz 1995: 106-108).

Although in legal terms the Länder gained some constitutional recognition of their share in the legislation and administration of Union-related matters, notably the newly won power to impose a Bundesrat opinion as binding on the Bund, the rules are so complicated that they can only work if Bund and Länder (and thus the federal parties comprising the governmental majority and opposition) continue to cooperate in a mutually compromising atmosphere. At the same time, it is still to be seen whether the Bundesrat will be able to translate its newly won legal powers in EU matters into formative political influence. The impression dominates that the Länder continue to restrict their rights to a simply reactive veto power in the Bundesrat trying to maintain the traditional balance of institutional powers with the federal government without initiating new political ideas to enhance the Bundesrat's role in European integration. Thus, together with the German parliaments, this chamber may factually be well regarded as one of the losers of Europeanizing the German governmental system in the long run (Sturm / Pehle 2001: $85)$.

As a consequence of the different adjusting processes due to dynamic EU integration, the German principle of executive/administrative dominance continues. The need for inter-Länder coordination through the Bundesrat means that regional Länder parliaments still lack effective access to the federal and European decision-making process. In the Bundesrat it is exclusively the executives that are engaged in permanent negotiations. The Länder delegates cannot be bound by state parliaments to follow a particular political line. European integration has induced various formal institutional adjustments in the German intergovernmental system but the adaptive pressures have not been able to change pre-existing national intergovernmental arrangements (Wessels / Rometsch 1996: 99; Olsen 2002: 934).

\section{Europeanization: a catalyst to domestic transformation?}

Although the German case offers no blueprint for the Europeanization of other EU member states with strongly decentralized or federalized governmental-administrative systems (like Belgium or Spain), it provides for some interesting insights which might be useful for further comparative purposes:

a) Federalism and decentralization is compatible with European integra- 
tion. The degree of federalization matters less than the structural and procedural features of the intergovernmental system that influence issues of compatibility between national and European dimensions.

b) In evaluating the impact of integration on national intergovernmental systems, the historically developed systemic national characteristics matter most. If analysis is restrained purely to power shifts between the different tiers of government, then Europeanization gives rise to systemic transformation and convergence of national systems of governance. But then the fact is not respected that German intergovernmental relations have integrated the EU dimension without endangering or seriously questioning the key features of its national model of government. Instead, Europe has affirmed and even reinforced German intergovernmental relations by extending them to the EU decision-making process (Goetz 1995: 111).

c) Finally, Europeanization may also work as a tool to legitimate politicalideological change, to internally stabilize the own model of regional economic success and to successfully export the competitive sub-national model to other European regions (Knodt 2000: 258). After the Maastricht debate the Länder shifted their interest in Europeanization from continuously developing their direct or indirect representation in Brussels to the protection of their exclusive competences in European governance. Therefore, in the framework of the Amsterdam Treaty the German Länder governments under the leadership of conservative Bavaria sought to secure their prerogatives over sectors of national legislation, especially concerning environment and immigration (Beuter 2002: 108). By ceasing to focus upon inter-institutional co-operation in EU matters, the Länder tried to strengthen the subsidiarity principle further by vigorously demanding its application in practice and thus expecting miore autonomy. In constitutional terms the Länder wanted a new clear delineation and re-distribution of competences between the EU, the federal government and the Länder, not excluding the re-nationalization of certain already Europeanized public policy sectors like agriculture (Leonardy 2002a: 129). At the same time, those of the economically more successful Länder that were ruled by the Christian-conservatives (then in the minority in the Bundesrat) also intended to make use of European subsidiarity for their own ideological and competitive advantages (Hüttmann / Knodt 2000: 37-38). By combining the discussions on subsidiarity at the EU-level, with those determining how to enhance the Union's problem-solving capacities and how to democratize the EU (and using positively determined terms like 'efficiency' 
and 'more transparency for the people') they tried to promote a systemic change from co-operative federalism to implementing more market competition in inter-Länder, as well as European inter-regional, relations (Wettbewerbsföderalismus). As expected, those objectives to vigorously reform European governance and German federalism by strengthening regional independence and individual responsibility met with resistance from the German Social-democrats. But the ideas continue to dominate the debate on reforming German federalism and re-exporting it in the EU that inspired this liberal political party platform a long while ago when Jacques Delors acted as president of the EU-Commission (Wachendorfer-Schmidt 2003).

\section{References}

Beuter, R. (2002). 'Germany: Safeguarding the EMU and the Interests of the Länder'. In Finn Laursen (ed.), The Amsterdam Treaty. National Preference Formation, Interstate Bargaining and Outcome. Odense: Odense University Press, 93-120.

Bielzer, L. (2003). Perzeption, Grenzen und Chancen des Subsidiaritätsprinzips im Prozess der Europäischen Einigung. Münster: LIT.

Böttcher, W. \& Krawczynski, J. (2002) Subsidiarität für Europa. Münster: LIT. Borkenhagen, F. H. U. et al. (eds) (1992). Die deutschen Länder in Europa. Baden-Baden: Nomos.

Bünder, H. \& Hajo, F. (2004). 'Europapolitik aus dem Ausschuß: Die Herrschaft der Beamten'. Frankfurter Allgemeine Zeitung (03/02), 19.

Caporaso, J. A., Cowles, M. G. \& Risse. T. (eds) (2001). Transforming Europe: Europeanization and Domestic Change. Ithaca, NY: Cornell University Press.

Chryssochoou, D. (2001). Theorising European Integration. London: Sage. Conrad, Ch.-M. (2003). Rechtliche Entwicklung der grenzüberschreitenden Zusammenarbeit von europäischen Regionen im Zeitalter der Globalisierung. Frankfurt am Main: Peter Lang.

Derlien, H.-U. (2000). 'Germany. Failing Successfully?'. In Hussein, K., Guy Peters, B. \& Wright, V. (eds) The National Co-ordination of EU Policy. The Domestic Level. Oxford: Oxford University Press.

European Commission (2001). European Governance. A White Paper. Luxembourg: Office for Official Publications of the European Communities Goetz, K. H. (1995). 'National Governance and European Integration: Inter- 
governmental Relations in Germany'. Journal of Common Market Studies, vol. 33, 1 (March), 91-116.

Hesse, J. J. \& Ellwein, Th. (1992). Das Regierungssystem der Bundesrepublik Deutschland, vol. 1, 7th ed. Opladen: Westdeutscher Verlag.

Hix, S. (1999). The Political System of the European Union. London: Macmillan Press.

Hölscheidt, S. (2001). 'The German Bundestag: From Benevolent "Weakness" towards Supportive Scrutiny'. In Maurer, A. \& Wessels, W. (eds) National Parliaments on their Ways to Europe: Losers or Latecomers? Baden-Baden: Nomos, 117-146.

Hopt, K. J., Kantzenbach, E. \& Straubhaar, T. (eds) (2003). Herausforderungen der Globalisierung. Göttingen: Vandenhoek und Ruprecht.

Hrbek, R. (1986). 'Doppelte Politikverflechtung: Deutscher Föderalismus und Europäische Integration'. In Hrbek, R. \& Thaysen, U. (eds) Die deutschen Länder und die europäischen Gemeinschaften. Baden-Baden: Nomos, 17-36.

Hüttmann, M. G. \& Knodt, M. (2000). 'Die Europäisierung des deutschen Föderalismus'. Aus Politik und Zeitgeschichte, 52-53: 31-38.

Ismayr, W. (2003). 'Das politische System Deutschlands'. In Ismayr, W. (ed.) Die politischen Systeme Westeuropas, 3rd ed. Opladen: Leske und Budrich, 445-486.

Jachtenfuchs, M. \& Kohler-Koch, B. (eds) (2003). Europäische Integration. 2nd ed. Opladen: Leske und Budrich.

Jeffery, Ch. (1999). 'Vom kooperativen Föderalismus zu eine 'Sinatra-Doktrin' der Länder?'. In Meier-Walser \& Hirscher (eds) Krise und Reform. 50-63.

Johansson, K.-M. \& Zervakis, P. A. (2002) 'Historical-Institutional Framework'. In Johansson, K.-M. \& Zervakis, P. A. (eds), European Political Parties between Cooperation and Integration. Baden Baden: Nomos, 11-28.

Katzenstein, P. J. (ed.) (1997). Tamed Power: Germany in Europe. Ithaka, NY: Cornell University Press.

Knill, Ch. (2001). The Europeanisation of National Administrations. Patterns of Institutional Change and Persistence. Cambridge: Cambridge University Press.

Knill, Ch. \& Lehmkuhl, D. (1999). How Europe Matters: Different Mechanisms of Europeanization. Bonn: Max-Planck-Projektgruppe Recht der Gemeinschaftsgüter, 9. 
Knodt, M. (2000a). 'Europäisierung a la Sinatra: Deutsche Länder im europäischen Mehrebenensystem'. In Knodt, M.\& Kohler-Koch, B. (eds) Deutschland zwischen Europäisierung und Selbstbehauptung. Frankfurt/Main: Campus, 237-264.

----(2000b). 'Europäisierung: Eine Strategie der Selbstbehauptung'. In Knodt, M.\& Kohler-Koch, B. (eds) Deutschland zwischen Europäisierung und Selbstbehauptung, Frankfurt/Main: Campus, 32-54.

Kohler-Koch, B. (2000). 'Europäisierung: Plädoyer für eine Horizonterweiterung'. In Knodt, M. \& Kohler-Koch, B. (eds) Deutschland zwischen Europäisierung und Selbstbehauptung, Frankfurt/Main: Campus, 11-31.

----(1998). 'Die Europäisierung nationaler Demokratien: Verschleiß eines europäischen Kulturerbes?' In Greven, M. (ed.). Demokratie - Kultur des Westens? Opladen: Leske und Budrich, 263-28.

Kühnhardt, L. (2003). 'Riese ohne Realitätssinn. Die EU-Integration wird die Steuerungskräfte unserer Politik begrenzen'. Rheinischer Merkur, 29 (17/07), 1.

Leonardy, U.' (2002a). 'Kompetenzabgrenzung: Zentrales Verfassungsprojekt für die Europäische Union'. In Zervakis \& Cullen (eds). Post-Nice Process. 129-151.

Leonardy, U. (ed.) (2002b). Europäische Kompetenzabgrenzung als deutsches Verfassungspostulat. Dokumente zu Entstehung und Außenwirkung des Artikels 23 GG. Baden Baden: Nomos.

Leslie, P. (2002). 'Finalité, Federalism, Flexibility'. In Zervakis \& Cullen (eds.). Post-Nice Process. 215-236.

Lijphart, A. (1999). Patterns of Democracy. Government Forms and Performance in Thirty-Sic Countries. New Haven: Yale University Press.

Luthardt, W. (1996). 'Europäischer Integrationsprozeß, deutscher Föderalismus und Verhandlungsprozesse in einem Mehrebenensystem: Beteiligungsföderalismus als Zukunftsmodell'. Staatswissenschaften und Staatspraxis, 7: 293-316.

Mair, P. (2000). 'The Limited Impact of Europe on National Party Systems'. Western European Politics, 23, 4: 27-51.

Meier-Walser, R. \& Hirschner, G. (eds.) (1999). Krise und Reform des Föderalismus. Munich: Olzog.

Milward, A. S. (1992). The European Rescue of the Nation State. London: Routledge. 
Moravcsik, A. (1998). The Choice for Europe. Social Purpose and State Power from Messina to Maastricht. Ithaka: Cornell University Press.

Nettesheim, M. (2003). 'Die konsoziative Föderation von EU und Mitgliedsstaaten'. In Burkhard Hess (ed.), Wandel der Rechtsordnung. Tübingen: Mohr Siebeck, 1-34.

Olsen, J. P. (2002). 'The Many Faces of Europeanization'. Journal of Common Market Studies, 40, 5: 921-952.

Pahl, M.-O. (2003). 'Deutsche Länder und EU. Involvierte Institutionen und Personen: Uberblick mit Internet-Adressen'. In http://www.jef.de/linebreak/shared/media/laender.pdf (accessed 01.12.2003).

Radaelli, C. M. (2000). 'Whither Europeanization? Concept Stretching and Substantive Change'. In European Integration online Papers, 4/8 (http://eiop.or.at/eiop/texte/2000-008a.htm) (accessed 05.02.2004).

Rosenau, J. N. (1969). 'Pre-Theories and Theories of Foreign Policy'. In Farrell, B. R. (ed.), Approaches to Comparative and International Politics. 2nd ed., Evanston: Nothwestern University, 27-92.

Scharpf, F. W. (1994). Optionen des Föderalismus in Deutschland und Europa. Frankfurt / Main: Campus.

Scharpf, F.W., Reissert, B. \& Fritz Schnabel (1976). Politikverflechtung: Theorie und Empirie des kooperativen Föderalismus in der Bundesrepublik. Kronberg: Scriptor.

Schmidt, M. G. (1999). Die Europäisierung der öffentlichen Aufgaben. Bremen: ZeS-Arbeitspapiere, 3.

Siedentopf, H. (1999). 'Implementation von EU-Richtlinien'. In Derlien, H.U. \& Murswieck, A. (eds), Der Politikzyklus zwischen Bonn und Brüssel. Opladen: Leske und Budrich, 83-103.

Statistisches Bundesamt (2004). 'Pressemitteilung vom 4. Februar 2004'. In http://www.destatis.de/presse/deutsch/pm2004/p0580033.htm (accessed 06.02.2004).

Steffani, W. (1997a). 'Die Republik der Landesfürsten'. In Steffani, W. Gewaltenteilung und Parteien im Wandel. Opladen: Westdeutscher Verlag, 56-88.

Steffani, W. (1997b). 'Regierungsmehrheit und Opposition'. in Steffani, W. Gewaltenteilung und Parteien im Wandel. Opladen: Westdeutscher Verlag, 125-151.

Sturm, R. (2003). 'Föderalismus und Regionalismus'. In Eckhard, J. \& Sturm, 
R. (eds). Demokratien des 21. Jahrhunderts im Vergleich. Opladen: Leke und Budrich, 113-138.

Sturm, R. \& Pehle, H. (2001). Das neue deutsche Regierungssystem. Die Europäisierung von Institutionen, Entscheidungsprozessen und Politikfeldern in der Bundesrepublik Deutschland. Opladen: Leske und Budrich.

Thunert, M. (2003). 'Think Tanks in Deutschland - Berater der Politik?' Aus Politik und Zeitgeschichte, B 51: 30-38.

Wachendorfer-Schmidt, U. (2003). Politikverflechtung im vereinigten Deutschland. Wiesbaden: Westdeutscher Verlag.

Wessels, W. (1997). 'The Growth and Differentiation of Multi-Level-Networks: A Corporatist Mega-Bureaucracy or an Open City?' In Wallace, H. \& Young. A. A. (eds), Participation and Policy-making in the European Union. Oxford: Oxford University Press.

Wessels, W. \& Rometsch, D. (1996). 'German Administrative Interaction and European Union. The Fusion of Public Policies'. In Mény, Y., Muller, P. \& Quermonne, J.-L. (eds), Adjusting to Europe. The Impact of the European Union on National Institutions and Policies. London: Routledge, 73-109.

Zervakis, P. A. (2004): 'Der Bologna-Prozess -Politische Vision oder pragmatische Antwort?'. Politische Studien, 393, 55 (January/February), 105-116. -(2003). 'Globalisierung und Europäisierung als Herausforderungen für den Wandel des Nationalstaats in Europa'. In Elm, R. (ed.), Ethik, Politik und Kulturen im Globalisierungsprozess. Bochum: Projekt Verlag, 280-317. Zervakis, P. A. \& Cullen, P. (eds) (2002). The Post-Nice Process: Towards a European Constitution? Baden-Baden: Nomos.

Zervakis, P. A. \& Yannis, N. (2001). 'The Parliament of Greece: Slow but Constant Moves towards European Integration?' In Maurer, A. \& Wessels, W. (eds), National Parliaments on their Ways to Europe: Losers or Latecomers? Baden-Baden: Nomos, 147-171. 